\title{
URBAN BIAS SEBAGAI PERANGKAP KETERBELAKANGAN PEMBANGUNAN DESA
}

\author{
Oleh: \\ Reuwih Diah Fitri Yani \\ Jurusan Pendidikan Geografi, Program Pascasarjana, UNY \\ reuwihdiah.2017@student.uny.ac.id
}

\begin{abstract}
Abstrak
Kegagalan pembangunan wilayah pedesaan yang menghasilkan keterbelakangan lingkungan merupakan proses dari sejarah panjang negeri ini. Munculnya konsep "urban bias" merupakan produk yang diwariskan oleh sejarah kolonialisme di negara-negara dunia ketiga, untuk menuju negara industrialis. Perkembangan teori-teori kolonial, imperialisme dan kapitalisme memberikan dampak sangat besar terhadap tercapainya pembangunan dalam arti sesungguhnya. Sistem pembangunan yang memusat menyebabkan dampak berantai di berbagai wilayah. Perindustrian, permukiman, kesenjangan sosial, urbanisasi hingga hilangnya kesempatan-kesempatan masyarakat di wilayah pedesaan adalah dampak yang dihasilkan oleh pandangan ini. Berbagai potensi dan permasalahan yang dimiliki oleh wilayah pedesaan sudah sepatutnya dikaji sebaik-baiknya dengan tujuan membuka seluas-luasnya kesempatan-kesempatan di wilayah pedesaan. Penentuan pandangan yang tepat pada wilayah pedesaan sesuai dengan karakteristiknya sehingga dapat menganalisa hambatan-hambatan nyata pada wilayah pedesaan. Konsep pembangunan "bottom-up" merupakan pembangunan yang dapat digunakan untuk penyusunan ulang wilayah pedesaan sehingga dapat memperbaiki akibat berantai yang dihasilkan oleh pembangunan masa lalu. Menggunakan konsep "urban bias" tulisan ini mencoba menelaah prasangka-prasangka masa lalu terhadap wilayah pedesaan sehingga dapat mengurangi kesalahan dalam sasaran pembangunan pedesaan melalui reorieontasi pandangan pembangunan.
\end{abstract}

Kata kunci: urban bias, keterbelakangan, desa.

\begin{abstract}
The failure of rural areas development which causes environmental backwardness is a long history process of the country. The emergence of "urban bias" concept is inherited by the history of colonialism in third world countries, to industrialist countries. The development of colonial theory, imperialism and capitalism have a huge impact on the achievement of development in the real sense. A centralized development system has resulted a chain of impact in different areas. Industry, settlement, sosial inequality, urbanization, and the decrease of community opportunities in rural areas are the impact of this view. The potentials and problems of rural areas are important to be examined to widely open the possible opportunities in rural areas. Determining appropriate views regarding rural areas based on their characteristics may reveal the visible problems in rural areas. The concept of "bottom-up" development is a development that can be used to rearrange territory to solve the problems resulted from the impacts of the past development. By using the concept of "urban-bias", this paper attempts to examine past prejudices against the rural areas therefore current fault of development targets for rural areas can be reduced through development view reorientations.
\end{abstract}

Keywords: urban bias, backwardness, rural. 


\section{PENDAHULUAN}

Perkotaan dan pedesaan merupakan kedua wilayah yang tidak dapat dipisahkan, baik dari segi fungsional maupun dari segi regionalnya. Penelaahan permasalahan di pedesaan merupakan kegiatan yang terintegratif dengan kondisi yang terjadi di wilayah perkotaan. Wilayah perkotaan merupakan wilayah awal pembangunan berasal, dimana wilayah pedesaan akan berkiblat dengan mengikuti perkembangan-perkembangan yang terjadi di wilayah perkotaan. Pembangunan dan perkembangan di wilayah perkotaan justru memberikan kesan keterbelakangan pada daerah pedesaan. Kegiatan-kegiatan yang terjadi di wilayah perkotaan berpengaruh secara langsung di wilayah pedesaan. Menurut Chambers (1988: 6), permasalahan di pedesaan terkait dengan keterbelakangan lingkungan karena kemiskinan harus dikaji dengan argumen bahwa pengkajian permasalahan tersebut dalam hubungan dengan ilmu pengetahuan yang berada di "inti" dan ilmu pengetahuan "pinggiran". Penggunaan kata "inti" dan "pinggiran" dalam pandangan tersebut berarti penelaahan masalah keterbelakangan di pedesaan merupakan penggabungan pemikiran tentang perkotaaan dan pedesaan. Pemikiran tersebut secara global menekankan pada perbedaan kehidupan antara masyarakat kaya dengan masyarakat miskin. Unsur kehidupan di kota yang berdampingan dengan unsur kehidupan desa. Industri yang kaya dengan status tinggi dan petani yang miskin dengan status pinggiran yang rendah.

Permasalahan yang terjadi di lingkungan pedesaan sangat erat kaitannya dengan kegiatan-kegiatan yang dilakukan di wilayah perkotaan. Wilayah pedesaan dianggap sebagai wilayah yang lekat dengan keterbelakangan terutama kemiskinan. Kemiskinan di wilayah pedesaan dipandang sebelah mata oleh masyarakat yang tinggal di wilayah perkotaan. Keadaan jalan yang tidak memadai, layanan transportasi yang buruk, pendidikan yang tidak merata hingga kemiskinan yang sulit untuk diselesaikan. Anggapan-anggapan masyarakat perkotaan terhadap masyarakat desa sangat mempengarahui keberhasilan berbagai pihak dalam menyelesaikan permasalahan keterbelakangan lingkungan di wilayah pedesaan.

Kajian kemiskinan di wilayah pedesaan merupakan tugas besar dari para pihak terkait yang menangani permasalahan keterbelakangan wilayah pedesaan. Kaum cendikiawan, biroktrat dan orang asing, para wartawan merupakan golongan orang-orang yang erat kaitannya dengan pemecahan permasalahan keterbelakangan masyarakat pedesaan. Penilaian dari golongan-golongan tersebut memberikan pengaruh yang besar terhadap pandangan dan solusi yang akan diberikan terhadap permasalahan di wilayah pedesaan. Banyak terdapat prasangka yang merintangi hubungan dengan kemiskinan desa pada umumnya, dan dengan kemelaratan pada khususnya. Prasangka-prasangka tersebut berlaku bukan hanya di kalangan para pembangunan desa, tetapi juga di kalangan para peneliti dan petugas lapangan yang hidup dan bekerja di daerah pedesaan dan bertugas untuk menelaah wilayah pedesaan. Chambers (1988) menyampaikan bahwa prasangkaprasangkan golongan-golongan tersebut terhadap kehidupan di pedesaan disebut dengan "urban bias".

Urban bias diartikan sebagai penyimpangan dari norma yang benar dan mengacu pada kondisi fisik objek dalam hal ini adalah kondisi pedesaan yang tidak sesuai dengan 
bobot atau kesesuaian yang nyata pada wilayah pedesaan (Lipton, 1991: 44). Lebih lanjut Michael Lipton menyampaikan bahwa kesalahan pandang masyarakat terhadap wilayah pedesaan dikarenakan tidak mendalamnya pengkaijian wilayah secara menyeluruh dari segi dikotomi kedua wilayah antara wilayah perkotaan dengan pedesaan.

Terdapat enam prasangka dari golongan-golongan tertentu terhadap wilayah pedesaan menurut Robert Chambers, yang disebut dengan "urban bias", yaitu prasangka keruangan, prasangka proyek, prasangka kelompok sasaran, prasangka musim kemarau, prasangka diplomatis, dan prasangka profesional. Keenam prasangka tersebut secara langsung dan secara tidak langsung berpengaruh terhadap pemecahan permasalahan keterbelakangan lingkungan di wilayah pedesaan, terutama pada pembangunan desa. Hasil dari pandangan-pandangan golongan tertentu terhadap wilayah pedesaan memberikan gambaran yang nyata kepada seluruh kalangan tentang bagaiman wajah wilayah pedesaan serta permasalahannya. Apabila prasangka-prasangka terhadap wilayah pedesaan dibiarkan begitu saja maka penyelesaian permasalahan keterbelakangan khususnya kemiskinan tidak akan benar-benar tepat pada sasaran, karena golongan-golongan tertentu yang memegang kendali atas pemecahan kemiskinan memiki pandangan yang salah terhadap wilayah pedesaan.

Hodder (2000: 59-60), menyatakan bahwa rencana pengembangan wilayah pedesaan memiliki kecenderungan bahwa faktor-faktor utama yang dikembangkan bukan pada bagian agriculture justru pada bagian non-agriculture, non rural dan urban-industrial problem. Kecenderungan pengembangan tersebut dikarenakan rencana pembangunan yang sudah diwariskan sejak peride kolonial dan masih eksis sampai saat ini pada beberapa negara. Berdasarkan teori Ruppert Hodder dapat diketahui bahwa prasangka "urban bias" tersebut merupakan hal yang sudah berlangsung sejak lama akan terus memberikan pandangan yang salah terhadap permasalahan di wilayah pedesaan apabila tidak memandang keadaan sesungguhnya di wilayah pedesaan dengan nyata dan aktual.

Prasangka-prasangka yang dihasilkan oleh urban bias menyebabkan semakin keterbelakangnya kondisi pedesaan, mulai dari kekurangan tenaga kerja, akses pendidikan, akses pelayanan umum, yang banyak ditinggalkan oleh penduduk pedesaan yang memasuki angka produktif untuk perpindah ke wilayah kota dengan tujuan untuk mendapatkan kesempatan dan kehidupan yang lebih baik (Roberta, 2012: 46).

Berdasarkan teori-teori yang disampaikan oleh Robert Chambers, Michael Lipton dan Ruppert Hodder tentang pembangunan wilayah pedesaan yang dipengaruhi oleh prasangka-prasangka "urban bias" terhadap wilayah pedesaan, maka tulisan ini akan menjelaskan apa saja prasangka-prasangaka yang ada pada wilayah pedesaan serta bagaimana brasangka-prasangka tersebut mempengaruhi rencana pembangunan wilayah pedesaan yang kaitannya pada kemiskinan di wilayah pedesaan.

\section{PEMBANGUNAN DAN KETERBELAKANGAN}

Pembangunan dan keterbelakangan merupakan kajian yang saling terkait satu sama lain. Pembangunan yang dilakukan di suatu tempat diikuti keterbelakangan yang sedang 
terjadi pula di tempat lain sebagai akibat dari pembangunan tersebut. Forbes (1986), mengemukakan bahwa keterbelakangan merupakan sebuah konsep geografisketerbelakangan bermakna diferensiasi geografis, pendapatan atau ukuran kesejahteraan yang dianggap sesuai. Ketika dikatakan bahwa suatu bangsa terbelakang maka yang dimaksudkan adalah suatu rakyat yang tinggal di tempat lain. Teori yang dirancang untuk membahas tentang keterbelakangan (misal Wallerstein) adalah teori geografi yang didasarkan pada asumsi mengenai pengalihan nilai dan surplus ekonomi di berbagai tempat.

Allen (2013: 167) menjelaskan "in development theory: from modernisation through to structuralism (encompassing dependency and world-system theory), then to poststructuralism and, most recently, to postdevelopment which of course is strongly informed by postmodernism". Lebih lanjut Allen (2013) menyatakan bahwa teori pembangunan dari masa ke masa selalu mengalami perubahan dari pandangan terhadap pembangunan pada structuralism berubah ke arah poststructuralism hingga postmodernism. Seperti pula yang disampaikan oleh Connell (2007: 122), bahwa pembangunan tidak hanya berupa kehancuran dari kebudayaan dan masyarakat tradisional sebagai akibat dari modernisasi kapitalis tersebut, merupakan pandangan dari teori pembangunan modernisasi. Pembangunan wilayah yang terjadi di wilayah perbatasan luar antara wilayah perkotaan dengan wilayah pedesaan tidak selalu menunjukan bahwa adanya perpindahan tenaga kerja yang ditarik oleh wilayah inti yang memiliki modal yang intensif tersebut adalah pandangan dari pembangunan strukturalis. Pandangan postmodern tentang pembangunan menyatakan bahwa pembangunan merupakan proses yang meliputi banyak hal terutama dalam hal politik, dimana dewan-dewan perwakilan rakyat baik lokal maupun internasional yang berwujud dalam bentuk pemerintahan dapat meningkatkan pendapatannya untuk menyediakan pelayanan umum yang baik dan menyelenggarakan fungsi-fungsi strategis dengan baik.

Perkembangan teori pembangunan dari waktu ke waktu menunjukan adanya perkembangan kebutuhan masyarakat baik di desa maupun di kota dalam setiap kegiatannya. Penduduk di wilayah pedesaan sebagian besar penghasilan yang diperolehnya digunakan untuk membayar biaya sekolah, bahan bakar, pakaian, hingga kebutuhan-kebutuhan dasar mereka yang harus terpenuhi.

Forben (1986: 68-70), menuliskan beberapa sebab-sebab keterbelakangan yang terjadi di negara-negara yang sedang berkembang, yaitu keterbelakangan merupakan suatu produk yang memang sengaja dibuat oleh sistem dunia, keterbelakangan merupakan hasil dari ketidakmerataan pembangunan ekonomi dan fisik wilayah, dan keterbelakangan merupakan hasil dari adanya hubungan saling ketergantungan yang menyebabkan kelangkaan, serta keterbelakangan merupakan 'set metal' masyarakat yang sudah tidak memiliki optimisme untuk maju karena seringnya mengalami kegagalan.

Rekayasa berbagai idealisme dimasukkan ke dalam koloni dunia yang membuat pembangunan seolah-olah berorientasi pada masyarakat kecil pada khususnya masyarakat pedesaan. Curry (2003) dan Banks (1999, dalam Allen 2013: 168), mengungkapkan bahwa kegiatan pembangunan perekonomian yang dilakukan di wilayah West New Britain dibuat 
menyerupai kegiatan pembangunan "praktik berbasis tempat" untuk para petani kecil dengan ungkapan untuk pertukaran hadiah dari masing-masing pihak yang mendapatkan keuntungan. Kegiatan tersebut dibuat untuk menjalin hubungan sosial yang baik dalam menciptakan modernitas pembangunan dengan berpegangan pada kelompok kecil yang berbasis pada ekonomi pasar yang tetap menjadi tujuan utamanya dari pembangunan ini. Pembangunan modernitas yang berpegang pada kekuatan pasar dengan menggerakan kelompok dari masyarakat pedesaan yang dianggap sebagai masyarakat kecil akan semakin mendorongnya ketergantungan-ketergantungan pada kegiatan perekonomian padat modal yang tidak dapat terhindarkan, sehingga tidak merangsang kemandirian masyarakat perdesaan yang justru semakin mendorong masyarakat kearah keterbelakangan.

Studi yang dilakukan oleh Stanef (2012: 44), di beberapa negara Uni Eropa terdapat ketidakmerataan pembangunan dalam berbagai faktor. Wilayah pedesaan menghasilkan 13\% GVA (Gross Value Added) dari total GVA nasional yang sisanya dihasilkan di wilayah perkotaan di Finlandia. Sektor primer seperti pertanian, perburuan, perhutanan dan perikanan yang menyumbang dalam pendapatan perkapita nasional hanya sekitar $6 \%$. Selain itu, layanan publik yang terkait dengan ketersediaan tenaga kerja di wilayah perdesaan hanya sekitar 63\% jika dibandingkan dengan aksesibilitas pekerjaan di wilayah perkotaan yaitu $74 \%$. Hasil studi tersebut menunjukan bahwa kesenjangan antara wilayah perkotaan dengan perdesaan merupakan hal yang sangat jelas terlihat terutama dalam pendapatan masyarakatnya.

Hubungan ketergantungan yang semakin kuat, dari waktu ke waktu akan memunculkan keterbatasan sumber daya, baik sumber daya energi, manusia hingga merosotnya mutu lingkungan. Data Nasional Rumania menyebutkan bahwa 70\% populasi penduduk pedesaan bekerja dibidang non enterpreuner sedangkan di wilayah perkotaan $60 \%$ penduduknya bekerja di bidang enterpreuner. Wilayah perkotaan yang memiliki penawaran yang banyak terhadap pekerjaan dan pelayanan lainnya, menyebabkan masyarakat pedesaan berbondong-bondong mendatangi wilayah perkotaan dengan tujuan untuk mendapatkan akses pekerjaan, pendidikan maupun akses di bidang lainnya. Terdapat tren urbanisasi di Indonesia yang menunjukan bahwa Indonesia sedang mengalami peralihan perekonomian yang didominasi oleh sektor pertanian ke perekonomian pada sektor jasa di perkotaan (ILO, 2015). Hal tersebut terbukti dengan data yang dikeluarkan oleh World Bank tahun 2014 menunjukan bahwa sektor primer memberi kontribusi sebesar $18,8 \%$ PDB, sedangkan sektor sekunder 32,9 \%, sedangkan sektor tersier sebesar $48,3 \%$.

Serban (2011), menyatakan bahwa kualifikasi keterampilan tenaga kerja di wilayah pedesaan sangat rendah sehingga tidak memungkinkan untuk mendirikan perusahaan di wilayah perdesaan. Hal tersebut dikarenakan ketergantungan masyarakat pedesaan terhadap wilayah perkotaan yang menyebabkan terjadinya zero zum di wilayah pedesaan.

Keterbelakangan masyarakat pedesaan terjadi pula karena adanya faktor mental yang sudah melekat pada masyarakat pedesaan. Banyaknya usaha yang sudah dilakukan oleh masyarakat pedesaan yang berakhir dengan hasil yang sama yaitu kegagalan 
menyebabkan banyak masyarakat pedesaan memilih untuk bersikap diam dan menerima segala keadaan yang melingkupi diri mereka. Keputusasaan masyarakat pedesaan terhadap kegagalan pembangunan bukan karena tidak bersedia untuk berpindah nasib dari miskin ke kaya, namun menikmati pendapatan dan kesempatan yang sudah mereka usahakan secara keras dan efektif merupakan pilihan akhir mereka (Lipton, 1991: 85).

\section{PERANGKAP “URBAN BIAS"}

Golongan yang menimbulkan urban bias adalah kaum cendekiawan, birokrat dan orang asing, serta para wartawan. Banyak terdapat prasangka yang merintangi hubungan dengan kemiskinan desa pada umumnya, dan dengan kemelaratan pada kususnya. Hal tersebut berlaku bukan hanya di kalangan pembangunan desa, tetapi juga di kalangan para peneliti dan petugas lapangan yang hidup dan bekerja di daerah pedesaan. Enam prasangka yang menyebabkan kemiskian di desa lepas dari pengamatan yaitu prasangka keruangan, prasangka proyek, prasangka kelompok sasaran, prasangka musim kemarau, prasangka diplomatis dan prasangka profesional (Chambers, 1988: 17-32).

Pengetahuan tentang kondisi daerah pedesaan diperoleh secara singkat dan tidak mendalam oleh para pelaku 'urban bias' yang menimbulkan penilaian yang tidak nyata pada daerah perdesaan. Lipton (1991: 42-44) menyatakan bahwa penilaian yang bias pada wilayah pedesaan dikarenakan ketidaktepatan penilaian dari wilayah pedesaan. Hal tersebut terjadi karena empat alasan yaitu, para penelaah tidak dapat menarik garis lurus antara pembagian wilayah pedesaan yang dekat dengan kota, pinggiran, taman dan pabrik desa. Ketidaktepatan dalam menentukan keberadaan sumberdaya yang dimiliki wilayah pedesaan yang sebenarnya ada dan bermanfaat atau yang tidak ada dan tidak bermanfaat. Penentuan wilayah pedesaan yang benar-benar mengalami kemiskinan dan yang sejahtera, dan kesalahan pengalokasian wilayah yang digunakan untuk pertanian, perindustrian pangan, investasi dan wilayah penduduk.

Halfacree (1993: 32), menyebutkan bahwa wilayah pedesaan merupakan wilayah yang dapat dijelaskan berdasarakan tempat dan gambaran sosialnya. Berdasarkan lokasinya, wilayah pedesaan merupakan wilayah yang secara spesifik memiki karakteristik tertentu dalam segi fisik dan sosial dalam wilayah tersebut. Wilayah pedesaan pada umunya dapat dianalisis pada beberapa hal; topografi, komposisi sosial dari manusia yang hidup dan atau pekerjaan, bentuk aktivitas, hubungan antara alam dengan manusia dan hubungan dengan wilayah yang lain dalam suatu lokasi. Jelas berdasarkan teori tentang wilayah pedesaan yang disampaikan oleh Halfacree (1993) bahwa wilayah pedesaan berarti bahwa lokasi yang memilki topografi beragam baik datar hingga bergelombang merupakan wilayah pedesaan sehingga sangat mempengaruhi persebaran sarana dan prasarana di dalam wilayah tersebut kaitannya dengan wilayah-wilayah yang dijadikan sasaran kunjungan untuk kegiatan pembangunan.

Konsep tentang wilayah pedesaan yang disampaikan oleh Halfacree (1993) dan Lipton (1991), menunjukan bahwa penilaian-penilaian kondisi fisik dan sosial masyarakat pedesaan yang tidak tetap dikarena tidak tepatnya telaah yang ilmiah pada kondisi nyata 
pedesaan. Kendala-kendala fisik yang dapat ditemui jika mengunjungi wilayah pedesaan menjadi alasan utama. Wilayah pinggiran kota yang masih dapat dengan mudah dilalui dari segi jalan raya, transportasi, biaya dan waktu.

Prasangka kota memusatkan kunjungan ke daerah-daerah pinggiran kota, khususnya dekat ke ibu kota dan pusat-pusat pemerintahan. Sebaliknya penyebaran rakyat desa yang miskin sering terlihat berbeda di daerah-daerah terpencil. Di daerah negara berkembang, rakyat miskin seringkali tergusur dari daerah padat penduduk, yang pelayanan angkutannya lebih baik, dan demi kelangsungan hidupnya, terpaksa menyingkir ke daerah terpencil di padang rumput dan kawasan hutan. Sukar dijangkau dari pusat-pusat kota, mereka pun hilang dari pandangan (Chambers, 1988: 17). Berdasarkan informasi yang dikeluarkan oleh Kementerian Pertanian melaui laman resminya, melakkukan kunjungan ke wilayah-wilayah yang memiliki aksesibitas yang mudah dan jauh dari arti keterbelakangan seperti kunjungan yang dilakukan di wilayah Palembang, Bandung, Ambon, yang merupakan wilayah-wilayah yang menjadi pusat kegiatan masyarakat dan bukan merupakan wilayah yang benar-benar memerlukan kunjungan nyata dari dinas terkait. Penilaian yang didapat dari wilayah pedesaan yang dijadikan sebagai sampel penilaian kemudian dibawa ke pusat dan kemudian akan dijadikan sebagai niali baku dari kondisi pedesaan yang berakhir pada kebijakan pembangunan yang tidak sesuai dengan kondisi nyata wilayah pedesaan.

Baik pembangunan desa maupun penelitian pedesaan, penuh dengan prasangka proyek. Penuntasan permsalahan di pedesaan dan peneilitian pedesaan pada umumnya merupakan sebuah program yang bertujuan untuk mencapai suatu hal dengan tekhnis yang sudah diatur sedemikian rupa. Prasangka proyek paling jelas adalah percontohan desa binaan dengan dukungan tenaga dan dana yang lebih dari cukup, diikuti oleh peserta yang sudah diajari dan tahu apa yang harus dikatakanya serta yang lokasinya tidak jauh dari kator pusat. Satu kajian penelitian akan memancing lebih banyak lagi kegiatan penelitian yang lainnya. Lagi-lagi kegiatan penelitian yang dilakukan di pedesaan bergerak menjauhi wilayah yang benar-benar membutuhkan. Tabel 1 menggambarkan tentang wilayah pedesaan yang pada umumnya digunakan sebagai percontohan penelitian permasalahan masyarakat pedesaan.

Kelompok masyarakat di wilayah pedesaan yang dihubungi dan didatangi oleh para pembangunan desa, para pejabat setempat dan peleiti pedesaan, serta tempat mereka menimba kesan dan informasi, adalah golongan di luar miskin. Kelompok-kelompok tersebut biasayanya merupakan golongan elit pedesaan seperti petani gresif, tokoh masyarakat, kepala desa, pedagang, pemuka agama, guru dan sebangsanya. Mereka inilah sumber informasi utama bagi masalah-masalah pedesaan. Lipton (1991: 63) menyebutkan bahwa urban bias disebakan karean adanya pengalokasian yang tidak merata. Dalam hal ini tidak merata diartikan sebagai informasi-informasi yang diperoleh sesuai dengan kriteria efesiensi dan ekuitas. Pemilihan sumber informan dalam menelaah permasalah pedesaan, para pembangunan desa akan mengikuti informasi mereka yang jelas dan diperhatikan dan menjadi kelompok-kelompok utama. Merekalah yang mengemukakan kepentingan dan 
keinginan masyarakat desa; sampai akhirnya terumuskan dalam urutan prioritas pembangunan untuk 'masyarakat desa' yang bersangkutan.

Tabel 1. Wilayah pedesaan yang digunakan sebagai percontohan penelitian permasalahan masyarakat

\begin{tabular}{|l|l|}
\hline Lokasi & Nama Desa \\
\hline Bantul, DIY & Poncosari, Selopamioro, Wukirsari, Srigading \\
\hline Kulonprogo, DIY & $\begin{array}{l}\text { Sidorejo, Tuksono, Giripurwo, Hargotirto, } \\
\text { Banjararum }\end{array}$ \\
\hline Gunung Kidul, DIY & $\begin{array}{l}\text { Beji, Giriharjo, Kemadang,Banyusoco, } \\
\text { Kebonrejo, }\end{array}$ \\
\hline Sleman, DIY & $\begin{array}{l}\text { Wukirsari, Purwobinangun, Sumbersari, } \\
\text { Wonokerto }\end{array}$ \\
\hline Blora, Jateng & Kebonrejo \\
\hline Banjarnegara, Jateng & Karangkobar, Gumelem Kulon \\
\hline Magelang, Jateng & Kalibening, Ngablak, Banyuroto, \\
\hline Klaten, Jateng & Krakitan, Jombaran \\
\hline
\end{tabular}

Sumber: Direktorat Pengabdian Kepada Masyarakat, UGM 2017.

Bagian terbesar penduduk dunia yang miskin mendiami daerah-daerah tropis, dengan musim penghujan dan musim kemarau. Bagi orang-orang yang hidup dan bercocok tanam, musim paceklik yang parah sering terjadi pada musim penghujan, terutama menjelang panen pertama. Pada waktu kehabisan bahan pangan, harga pangan naik, dan pekerjaan semakin sulit didapat, maka penyakit pun mulai berjangkit. Menurut World Economic Outlook Database (IMF) 2017, terdapat beberapa negara miskin di dunia yang memiliki PDB per kapita paling rendah yaitu, Republik Afrika Tengah, Republik Demokratik Kongo, Burundi, Liberia, Niger, Malawi, Mozambik, Guinea, Eritrea, dan Madagaskar. Ke sepuluh negara tersebut berdasarkan data yang dikeluarkan oleh IMF merupakan negara dengan total PDB kurang atau sama dengan US\$. 1.500.000. rata-rata dari kesepuluh negara termiskin tersebut berada pada wilayah tropis, bukti tersebut mendukung hipotesis yang diajukan oleh Robert Chambers.

Indonesia sebagai negara yang berada di negara tropis tidak terhindarkan pula dari adanya prasangka perkotaan mengenai prasangka musim. Berikut data mengenai wilayahwilayah termiskin di wilayah Indonesai menurut Badan Puasat Statistik Indonesia tahun 2017 yaitu wilayah Nias Utara, Kepulauan Meranti, Lombok Utara, Sumba, Maluku Barat Daya, Teluk Wondama dan Bintuni, dan sebagain besar di wilayah Papua yaitu, Sorong, Tambrauw, Pegunungan Arfak, Jayawijaya, Paniani, Puncak Jaya, Yahukimo, Lanny Jaya, Membramo Tengah, Intan Jaya dan Deiyai.

Wilayah-wilayah yang menjadi wilayah terbelakang meneurut data yang dikeluarkan oleh BPS tahun 2017, merupakan wilayah yang memiliki pendapatan daerah paling rendah. Sebagain besar wilayah tersebut merupakan wilayah yang berada jauh dari pusat 
pemerintahan. Misalnya wilayah yang berada di Papua dan Sumba merupakan wilayah yang memiliki aksesibilitas yang sangat rendah, sehingga kunjungan dan penelitian di wilayahwilayah tersebut sangat jarang dilakukan. Akibatnya adallah ketidak merataan pembangunan yang menghasilkan keterbelakngan seperti yang terjadi di wilayah-wilayah termiskin tersebut.

Robert Chambers menyatakan bahwa orang kota sering dihinggapi dengan rasa rikuh dalam mengahadapi rakyat desa yang miskin, karena hambatan rasa sopan-santun dan malu; mereka takut mendekati, menumui, mendengarkan dan belajar dari rakyat desa. Kemiskinan dalam suatu negeri dapat menjadi masalah yang tidak diperhatikan atau memalukan sebagai hal yang lebih baik ditutupi atau secara psikologis ditekankan kebawah sadar. Sopan-santun dan sikap hati-hati yang berlebihan biasanya menutupi pertanyaan yang akan membuat rikuh, kunjungan ke rumah mereka yang kumuh, diskusi dengan wanita-wanita yang sedang bekerja, atau wawancara dengan suku apa. Sopan-santun dan kekecutan hati, merupakan pemisah antara 'orang luar' dengan rakyat miskin.

\section{PEMECAHAN PANDANGAN “URBAN BIAS”}

Kesalahan pandangan dan penilaian masyarakat perkotaan terhadap masyarakat pedesaan sudah seharusnya mendapatkan tanggapan yang serius. Pembangunan dan keterbelakangan yang semakin tidak bisa menemukan titik imbangnya adalah permasalahan besar. Negara dikatakan sebagai negara yang berhasil jika pembangunan fisik dan manusianya mengalami keseimbangan sehingga tidak menimbulkan banyak konflik dalam kehidupan masyarakatnya. Kesalahan pandangan terhadap wilayah pedesaan yang menimbulkan banyaknya persepktif yang tidak tepat mendorong orientasi pembangunan yang salah sasaran di wilayah pedesaan.

Pedesaan tidak hanya lekat dengan pengaruh-pengaruh buruk yang terdapat di dalamnya, namun wilayah pedesaan memiliki pula pontensi yang dapat digunakan dan dikembangkan dalam rangka untuk mengurangi ketergantungan dengan wilayah perkotaan yang dapat mendorong semakin tingginya keterbelakangan lingkungan pedesaan. Stanef (2012: 50) menjelaskan wilayah pedesaan harus dinyatakan dalam pembedaan yang jelas tentang keadaan alam dan topografi, budaya dan kondisi penduduk yang mempengaruhi keadaan sosial dan ekonominya terutama dalam rangka upaya pembangunan. Menganalisis potensi-potensi yang nyata di wilayah pedesaan merupakan hal yang seharusnya supaya dapat menghilangkan prasangka-prasangka yang tidak benar di wilayah pedesaan.

Natural protected merupakan sebuah paradigma yang dapat digunakan pada suatu wilayah untuk menghilangkan prasangka-prasangka yang sudah terlanjur menjadi paradigma lama dalam penelaahan permasalahan di perdesaan. Pallares (2012: 87) menjelaskan pentingnya Kawasan Lindung Alam (NPA) di daerah-daerah periferi seperti Indonesia sebagai titik fokus tertentu dalam strategi kepentingan lokal yang berbasis pedesaan dengan mengintegrasikan wacana konservasi dan wacana pembangunan pedesaan. 
Natural Protected Area (NPA) merupakan sebuah paradigma baru dalam pembangunan yang secara prinsip tentang konservasi namun tetap menanggapi isu-isu lokal di perdesaan seperti kelangkaan sumberdaya, strategi pembangunan daerah, sumber daya manusia dan ekonomi, dengan hal ini NPA bertujuan untuk meningkatkan peran pedesaan atau lokal dalam pembangunan yang berbasis konservasi (Naughton-Treves dan Brandon, 2005).

Prados (2009) menyampaikan bahwa, sektor primer di wilayah pedesaan yang pada mulanya merupakan sektor pertanian kini sudah tidak lagi menjadi faktor kegiatan utama di wilayah pedesaan. Sektor pertanian tidak lagi kompetitif di berbagai daerah untuk menjadi sumber utama kehidupan masyarakat pedesaan. Pertanian saat ini sudah mengalami pergeseran pandang yang dari mulanya sebagai faktor produktif sekarang beralih ke faktor sosial. Rekonstruksi wilayah pedesaan melalui banyak tahap mulai dari diversifikasi pertanian (McNally, 2001), pluriactivity dan pertanian paruh waktu (Evans et al.., 1993). Sebab itu wilayah pedesaan sudah mengalami banyak perkembangan pembangunan dari waktu ke waktu.

Pallares (2012: 89) menyampaikan bahwa naturbanisasi merupakan sebuah konsep yang menganalisa dinamika perkotaan dan pedesaan yang baru dalam konteks dinamika pedesaan-perkotaan yang menjadikan wilayah pedesaan sebagai karakteristik utama komoditi ekonomi. Konsep naturbanisasi di sampaikan pula oleh Marsden (2003); Cloke (2006); Elbersen (2005). Prados (2005), menjelaskan akibat dari adanya Narutal Protected Area (NPA) akan mendorong semakin kuatnya arus naturbanisasi. Naturbanisasi ini merupakan konsep yang dapat digunakan sebagai penyeimbang dari konsep urbanisasi yang menjadikan kota sebagai magnet utama dari dinamika penduduk. Dengan adanya penyeimbangan perpindahan penduduk maka wilayah pedesaan tidak akan mengalami keterbelakangan karena ditinggalkan oleh penduduknya ke wilayah perkotaan. NPA juga dapat merangsang pertumbuhan ekonomi wilayah pedesaan karena aktivitasnya bergantung pada warisan alam dan memiliki potensi besar dalam ekonomi lokal.

Brodda (2007), pemanfaatan kawasan lokal atau daerah merupakan pembangunan pedesaan yang terpadu. Pembangunan pedesaan terpadu dapat merangsang kebijakan pemerintah yang berbasis wilayah pedesaan. Akibatnya terdapat aktor-aktor baru dalam pembangunan di wilayah pedesaan seperti lembanga dan kemitraan, folunter serta institusi swasta untuk terlibat dalam pembangunan daerah secara tidak langsung. Dengan dilakukannya pembangunan pedesan yang terpadu melalui Natural Protected Area (NPA) dapat mengurangi sedikit demi sedikit prasangka-prasangka perkotaan terhadap wilayah pedesaan dan akan berdampak pada orientasi pembangunan yang dilakukan oleh pemerintah pada khususnya.

\section{SIMPULAN}

Pembanguanan dan keterbelakangan merupakan satu rangkaian yang saling terkait dan tidak dapat dipisahkan satu sama lain. Keterbelakangan di wilayah pedesaan muncul karena tidak terdapat keseimbangan pembangunan yang dilakukan di wilayah perkotaan. Penyumbang tersebar dalam kegagalan pembangunan di wilayah perdesaan adalah 
kesalahan pandang aktor-aktor berpengaruh dalam membuat pandangan terhadap kondisi pedesaan baik fisik maupun kondisi sosial masyarakatnya. Urban bias merupakan kosep yang masih relevan samapai sekarang ini, dan masih mempengaruhi orientasi pembangunan di wilayah pedesaan.

Prasangka-prasangka perkotaan terhadap wilayah pedesaan yaitu, prasangka keruangan, prasangka proyek, prasangka kelompok sasaran, prasangka musim kemarau, prasangka prasangka diplomatis, dan prasangka prasangka profesional. Keenam prasangka tersebut secara langsung dan tidak langsung menjadikan frame wajah wilayah pedesaan selama ini. Dan akibat berantainya adalah ketidaktepatan sasaran pembangunan yang dibutuhkan secara nyata di wilayah pedesaan.

Natural Protected Area merupakan salah satu paradigma baru yang dapat digunakan sebagai pandangan untuk menggeser prasangka-prasangka yang tidak sesuai pada wilayah pedesaan. Paradigma ini memberikan dampak yang signifikan terhadap arus perpindahan penduduk yang semula berorientasi pada wilayah perkotaan sekarang berbalik ke wilayah pedesaan. Selain itu paradigma tersebut dapat menumbuhkan kemandirian masyarakat di wilayah perdesaan dengan memanfaatkan kemampuan lokal sebagai sumber kehidupan selain dari sektor pertanian.

\section{UCAPAN TERIMA KASIH}

Pada kesempatan kali ini penulis menyampaikan terimakasih kepada ibu Dr. Hastuti, M.Si selaku Dosen Pembimbing dalam penyusunan tulisan ini, yang telah memberikan bimbingan, arahan, saran dan masukan selama proses penulisan hingga terselesaikannya tulisan ini.

\section{DAFTAR PUSTAKA}

Allen, M.G. 2013. Rural Development: Back on the Agenda in the Western Pacific?. ANU Press.

Banks, G. 1999. 'Business as usual', in C. Filer (ed.), Dilemmas of Development: The Social and Economic Impact of the Porgera Gold Mine. Canberra: Research School of Pacifi and Asian Studies, The Australian National University.

Brodda, Y. 2007. New Regional Development Concepts for Rural Peripheries Experiences from there European Case Studies: Western Isles and Skye and Lochalsh. Scotland; Jamtland, Sweden and Eisenwurzen, Austria. (Thesis to be published in 2009 Gottingen, Germany).

Chambers, R. 1988. Rural Development Putting The Last First. Pembangunan Desa: Mulai Dari Belakang. LP3ES: Yogyakarta. Penerjemah: M. Dawam Rahardjo.

Cloke, P. 2006. 'Conceptualizing rurality', in P. Cloke; T. Marsden \& P.H. Mooney (eds). Handbook of Rural Studies: London/Thousand Oaks/New Delhi.

Connell, J. 2007. 'Islands, idyll and the detours of development'. Singapore Journal of Tropical Geography. 28(2): 116-135.

Curry, G. 2003. Moving Beyond Postdevelopment: Facilitating Indegenous Alternatives for 'Development'. Economic Geography. Vol 79, No 4, pp.405-423. 
Direktorat Pengabdian kepada Mayarakat. 2017 . Program Pengabdian Kepada Mayarakat Berbasis Pengembangan Desa Binaan. Universitas Gadjah Mada.

Elbersen, B. 2005. Combining Nature Conservation and Residential Development in the Netherlands, England and Spain. Journal of Environtmental Planning and Management. Vol 48:1, pp. 37-63.

Evans, N. J dan Ilbery, B. 1993. The Pluriactivity, part-time farming and farm disertivication debate. Environmental and Planning. A Vol, 25:7, pp. 945-959.

Forbes, D. K. 1986. Geografi Keterbelakangan Sebuah Survai Kritis. LP3ES: Yogyakarta.

Halfacree, K. H. 1993, 'Locality and social representation: space, discourse and alternative definitions of the rural', Journal of Rural Studies, vol. 9, no. 1, pp. 23-37.

Hodder, R. 2000. Development Geography. New York: Routledge.

ILO. 2015. Tren Ketenaga kerjaan dan sosial di Indonesia tahun 2014-2015: Memperkuat Daya Saing dan Produktivitas Melalui Pekerjaan Layak. Jakarta: Kantor Perburuhan Internasional.

Lipton, M. 1991. Why Poor People Stay Poor. Urban Bias In Worldd Development. ANU Press.

Marsden, T. 2003. The Condition of Rural Sustainability: Issue in the governance.

Mcnally, S. 2001. Farm disertivication in England and Wales-What can we learn from the farm bussiness survey? Journal of Rural Studies. Vol, 17, pp. 247-257.

Naughton-Treves, L; Brandon K. 2005. 'The Role of Protected Areas in Conserving Biodiversity and Sustaining Local Livelihoods'. Annual Review of Environmental Resources. Vol, 30, pp. 219-252.

Pallares, M. 2012. Natural Protected Areas and Rural/Local Development: A Sustainable Strategy in Remote Areas. Urbanisation Institution Republic Slovenia.

Prados, MJ. 2005. Territorial Recognition and Control of Change in Dynamic Rural Areas: Analysis of the Naturbanization Process in Andalusia, Spain. Journal of Environtmental Planning and Management. Vol, 48 (1), pp. 65-83.

Prados, M.J. 2009. 'Conceptual and Methodological framework of naturbanization' in M. J Prados (eds). Naturbanization: New identities and processes for rural-natural areas. (Taylor and Francis Group, London).

Roberta, M. 2012. Measuring Differences In Urban Rural Development: The Case Of Unemployment. Theoretical and Empirical Researches in Urban Management, Vol. 7, No. 3, pp. 44-52.

Serban A, C. 2011. The crisis impact on youth employment. Revista Economica Sibiu. Vol, 2(55), pp. 17-25.

Stanef, M. R. 2012. Measuring Differences In Urban Rural Development: The Case Of Unemployment. Theoretical and Empirical Researches in Urban Management, Vol. 7, No. 3, pp. 44-52. 